\title{
THE ARKHANGELSK DIAMOND-KIMBERLITE PROVINCE - A RECENT DISCOVERY IN THE NORTH OF THE EAST-EUROPEAN PLATFORM.
}

\author{
Sinitsyn $^{(1)}, A . V . ;$ Ermolaeva $^{(1)}, L . A$. and $G^{(2 i b}{ }^{(2)}, V . P$.
}

(1) Research Institute "Horizon", Leningrad State Univ. Petrodvorets. 198904, U.S.S.R.; (2) Geological Enterprise "Arkhangelskgeologia", Arkhangelsk, 163001, U.S.S.R.

The discovery, in 1970-1980, of kimberlites in the north part of the East-European platform might have happened earlier had prospecting followed promptly upon correct data interpretation. In 1936, in the vicinity of Nenoksa, on the Onezhsky Peninsula on the White sea coast, instead of the expected Paleozojc sediments, a random hydrogeological borehole intersected exotic breccia. It was interpreted by different geologists as variously greywacke, basic tuff,agglomeratic breccia, etc. The nature of this breccia remained doubtful until 1968 when a routine ground magnetic survey around Nenoksa revealed local magnetic anomalies of 400-2000 gammas intensity, one of which coincided with the old Nenoksa borehole. Boreholes drilled to check the anomalies disclosed a group of explosive pipes filled by eruptive breccia. Petrographic investigations of the pipe rocks determined picrite-porphyrites and nondiamondiferous kim berlites (Sinitsyn et a].,1973) and, later on melilitic picrites. The red colour of the pipe rocks, due to country rock con tamination, was unusual, and served as a psychological barrier to their recognition at first. It was discoverd later, that the pipes usually become dark green at depth. The aiscovery of the Nenoksa pipes led to the recognition of a significant new magmatic complex in the region and the initiation of prospecting for diamond-bearing kjmberlites (Sinjtsyn eat al, 1973; Stankovsty et al.,1973).

The Nenoksa pipes comprise a field on the northeastern border of the Onezhsky Riphean (ca.1800 Ma) buried rift and are situated in the zone of the diagonal Verkhovsky fracture. They are represented by vertical vents oval to subround in plan, up to $425 \mathrm{~m}$ in diameter. At the time of writing, about 30 pipes have been discovered, but the total number may be much higher. They intrude argillites of the Upper Proterozoic Redkinsky formation and are covered by Quaternery moraine. Xenoliths of fossil. wood indicate a maximum age of Devonian-Middle Carboniferous.

Investigators noted the world-wide trend of kimberlitic magmatism to localise in the border zones of interplatform syneclises or broad crustal downwarps, therefore included tectonic analyses of the northern part of the East-European platform in the next stage of investigation. The $1000 \mathrm{~km}$-long Arkhangelsk trend of Late Proterozoic-Early Paleozoic tectonic activity was readily detected on satelitite images (Sinitsyn et al.,1982) from Onega Lake northeastware to Kanin Nos Peninsula. The entire zone was regerded as prospective for kimberlite occurence (Sinitsyn et al.,? 132 ). The first step included higr precision airborne magnetic survey followed by geological mapping inside the zone adjacent to the Nenoksa area of the winter coast of the White Sea. Simulteneously radar airborn mapping was initiated for the entire Arkhangelsk tectonic activation trend of about $204000 \mathrm{~km}^{2}$ aiming for photoanomalies of the pipe type. Geological mapping resulted in 1976 in the discovery of small kimberljte sills, cropping out along the bank of the Mela River. 
Checking of the pipetype magnetic anomalies started in 1980, and the first borehole drilled on the winter Coast intersecred the Pomorskaya kimberlite pipe. The debates " whether pink-reddj.sh breccias are kimberlites or not ceased after economic diamonds were assayed in them. The subseguent prospecting search resulted in the discovery of about 50 pipes on the winter Coast, 15 of which were proven to be diamondiferous. Several neighbourj.ng fields or clusters are distinguished - Zolotitsa, Verkhotinskaya, kepino, Mela, Izhmozero and Poltozero.

The general geological setting of the winter coast pipes is much the same as that of the Nenoksa field the pipes intrude the Upper Proterozoic (Vendian) strati and are transgressively covered by Carboniferous, Permian and Quaternary rocks They contain xenoliths of carbonized wood and Ordovician rocks, suggesting Devonian age.SHRIMP analyses

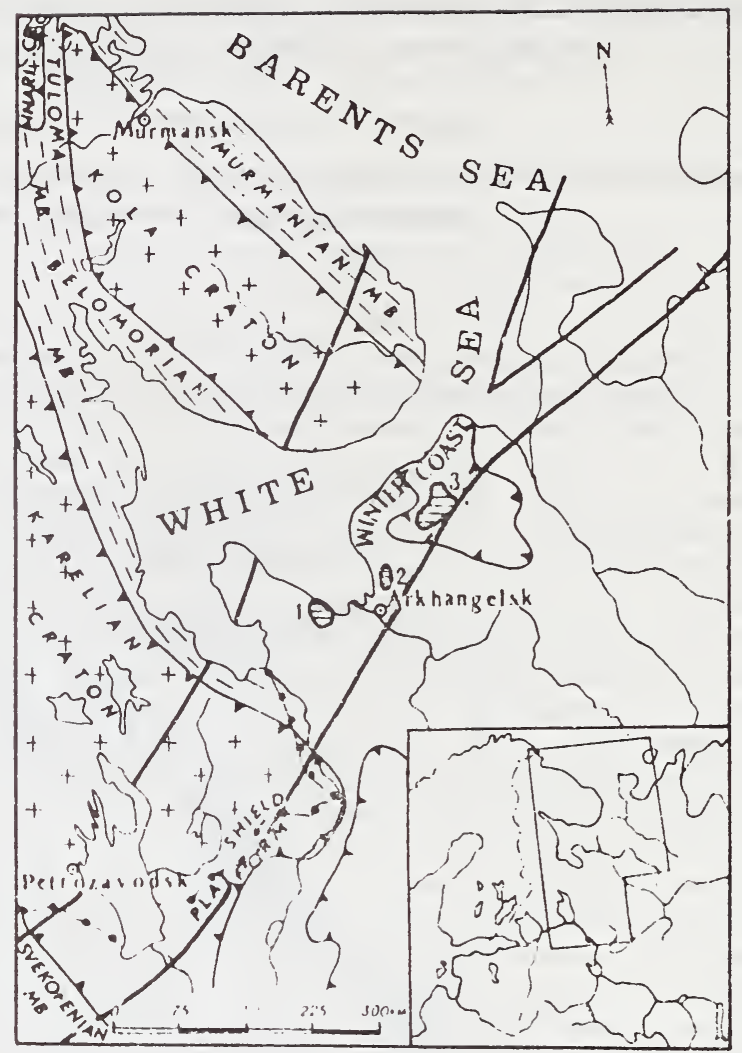

of perovskite from Pionerskaya pipe performed by Anglo-American Research Laboratories yielded $462 \mathrm{mln} \cdot \mathrm{y}$., which is Ordovician. Porphiritic and autolithic kimberlites (TKB) are predominant, with monophase and polyphase pipes being equally abundant. Some of the pipes retained the crater facies - the so called "sedimentary kimberlites" up to $250 \mathrm{~m}$ thick. The area of individual pipes ranges from $6000 \mathrm{~m}^{2}-2.5 \mathrm{~km}^{2}$.

The Winter coast pipes are classified according to their composition into four groups: (1) high magnesium kimberlites (Zolotitsa group and two pipes of Kepino group), (2) high iron kimberlites (Verkhotinskaya group, several pipes of the Kepino group and Mela sill), (3) alkaline picrites, including alnoitetype melilite picrites (most pipes of the Kepino group and adjoi ning Izhmozero field), and (4) fresh basaltic pipes of tholciitic affinity (Poltozero group). Only kimberlite pipes have proven to be diamondiferous.

The boundaries of the buried Kuloi craton, Karelean and Kola Archaean cratons, and the surrounding Proterozoic mobile belts are shown on the Fig. It is obvious that all diamondiferous kimberlite pipes are confined to the Kuloi cratonic area. Several kimberlite fields form a vast zone about $1000 \mathrm{~km}$ long within Arkhangelsk tectonic trend, predicted from radar mapping data. A problem of selecting promising target areas reisulted. Under these circumstaces, the South African prospccting experience as presented by T. Clifford's rule (Clifford, 1966) assumed special importance, i.e. all economic diamond-bearing kjmberlite pipes are found inside Archaean cratonic areas. 
Structural analyses of the Arkhangelsk province from Clifford's point of view was feasible only by interpreting the tectonic framework of the East-European platform according to the South African model of Archaean cratons and Proterozoic mobile belts. At first, the model appeared discordant with Soviet geology, but, cosidering the possible prospecting return, tempting enough to try.

The main conclusions resulting from this exercise follow; 1. The Arkhangelsk activation trend is a border tectonic zone along the western rim of the Vendian-Paleozoic basin of the Russian plate. It obliquely transects the heterogenous Precambrian basement.

2. The known kimberlite fields of the Arkhangelsk province reveal two different structural settings: a) the Zolotitsa (productive) group of fields has an intercratonic setting, and b) the Nenoksa and Izhmozero (nonproductive) fields are within the Belomorian mobile belt.

Hence, Clifford's rule specifying intercratonic setting for diamondiferous pipes has been proven to be valid.

In summary, it must be conceded that the tectonic controls proposed for the Arkhangelsk province, including structural directions and trends of tectonic activation can be validly applied only to the northern part of the platform.Furthermore, reported recently occurences in the Ukraine, Belorussia, Novgorod district, Estonia, Sweden and Kola Peninsula reveal a different structural pattern and were subjected to different tectonic controls. Each occurence requires individual study.

The Arkhangelsk discovery puts the East European platform in a row with the South African and the East Siberian provinces ventually might be of comparable diamond potentials. 